
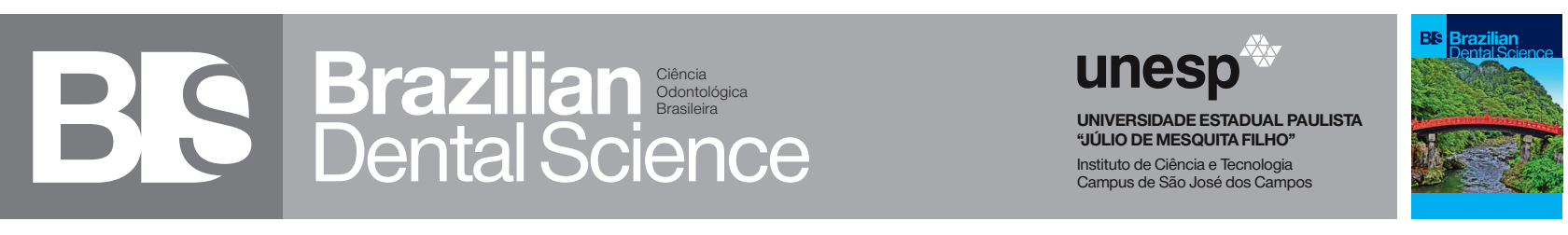

\title{
Effect of beverages with different alcoholic concentration on composite resins
}

Efeito de bebidas com diferentes concentrações alcoólicas em resinas compostas

\author{
Laís Andrade LA-GATTA ${ }^{1}$, Alexandre Marques de RESENDE², Luís Felipe Marques de RESENDE ${ }^{3}$, Rafael Barroso PAZINATTO²; Igor \\ do Carmo de SOUZA ${ }^{1}$, Antônio Márcio Resende do CARMO ${ }^{4}$ \\ 1 - Faculty of Dentistry - Federal University of Juiz de Fora - Juiz de Fora - MG - Brazil. \\ 2 - Department of Restorative Dentistry - Faculty of Dentistry - Federal University of Juiz de Fora - Juiz de Fora - MG - Brazil. \\ 3 - University of Taubaté - Taubaté - SP - Brazil. \\ 4 - Department of Dental Clinic - Faculty of Dentistry - Federal University of Juiz de Fora - Juiz de Fora - MG - Brazil.
}

\section{ABSTRACT}

Objective: To evaluate if alcoholic beverages can cause color change in composite resins, if the alcoholic concentration influences this variation besides analyzing within the composite resins tested, which would present greater color stability when subjected to the experiment. Material and Methods: 90 specimens of three different composite resins (IPS Empress Direct, GrandioßSo and Filtek Z350 XT) were immersed in distilled water (control group), red wine and vodka. The samples were $2 \mathrm{~mm}$ thick and $8 \mathrm{~mm}$ in diameter, photopolymerized for $20 \mathrm{~s}$ on each side, polished with sandpaper, silicon carbide tip and felt disc with prophylactic paste and immersed in distilled water at $37{ }^{\circ} \mathrm{C}$ for $24 \mathrm{~h}$ prior to subgrouping. For the evaluation of the color variation, the formula prioritized by the CIEL *a * $b$ * system was used. Data were analyzed by ANOVA and Tukey's test at 95\% significance. Results: The lowest variations occurred with the GrandioßSo resin when exposed to wine, and Filtek Z350 XT when exposed to vodka. There was a statistically significant difference between the groups in water $(\mathrm{p}<0.01)$ and in red wine $(\mathrm{p}<0.01)$, but not in vodka ( $\mathrm{p}>0.05)$. The soaking medium that most caused staining was red wine. Conclusion: Red wine was the drink that generated the highest staining in all the resins tested, vodka did not change color stability significantly, the alcoholic concentrations tested did not directly influence the color change and the composite resin Grandio ${ }^{\circ}$ So presented greater color stability when exposed to red wine.

\section{KEYWORDS}

Alcoholic beverage; Color; Composite resin.

\section{RESUMO}

Objetivo: Avaliar se bebidas alcóolicas podem provocar alteração de cor em resinas compostas, se a concentração alcóolica tem influência nesta variação além de analisar dentre as resinas compostas testadas, qual apresentaria maior estabilidade de cor quando submetidas ao experimento. Material e métodos: Foram confeccionados 90 espécimes de 3 diferentes resinas compostas (IPS Empress Direct, GrandioßSo e Filtek Z350 XT) e imersos em água destilada (grupo controle), vinho tinto e vodca. As amostras mediam $2 \mathrm{~mm}$ de espessura e $8 \mathrm{~mm}$ de diâmetro, foram fotopolimerizados por $20 \mathrm{~s}$ cada lado, polidos com disco de lixa, ponta de carbeto de silício e disco de feltro com pasta profilática e imersos em água destilada a $37^{\circ} \mathrm{C}$ por 24 h antes da divisão em subgrupos. Para a avaliação da variação de cor foi utilizada a fórmula priorizada pelo sistema CIEL*a*b*. Os dados foram analisados por ANOVA e teste de Tukey a 95\% de significância. Resultados: As menores variações ocorreram com a resina GrandioßSo quando exposta ao vinho, e a Filtek Z350XT quando exposta à vodca. Houve diferença estatisticamente significante entre os grupos na água ( $\mathrm{p}<0.01)$ e no vinho tinto ( $\mathrm{p}<0.01$ ), mas não na vodca ( $\mathrm{p}>0,05)$. O meio de imersão que mais causou manchamento foi o vinho tinto. Conclusão: $O$ vinho tinto foi a bebida que gerou o maior manchamento em todas as resinas testadas, a vodca não alterou a estabilidade de cor de maneira significativa, as concentrações alcóolicas testadas não influenciaram diretamente na alteração de cor e a resina composta Grandio $® S o$ apresentou maior estabilidade de cor frente ao vinho tinto.

\section{PALAVRAS-CHAVE}

Bebida alcóolica; Cor; Resina composta. 


\section{INTRODUCTION}

$\mathrm{T}$ oday, the aesthetic ideal prevails in every society, generating an increasingly expressive search for procedures that aim to reestablish aesthetics and smile. The composite resins have been widely used for their excellent aesthetic properties, being considered as materials of first choice for restorative treatments for this purpose $[1,2]$.

Among the main factors of composite resin staining is the degradation of the organic matrix (by poor polymerization), surface irregularity and sorption of water, which allows the penetration of low molecular weight dyes [3]. Due to this latter property, several studies show that there is color change when there is contact between drinks and resins, because the resins are able to absorb other fluids besides water [4]. The discoloration can be classified according to its origin as: intrinsic and extrinsic discoloration. In the intrinsic, the photoinitiating agent is permanently related, and also influencing the color stability of the type of inorganic matter and accelerator component are the quality and quantity of the polymer. The external sources of contamination such as food habits, hygiene and chemical properties of the compound are related to extrinsic $[5,6]$. Thus, external staining occurs due to the accumulation of bacterial plaque and superficial spots [7]. Also keen to the tendency to discoloration and susceptibility to dyes, resins with a low degree of conversion, quality of the polishing, the composition and volume of the organic matrix and the charge particles $[5,6]$.

Chemicals present in alcoholic beverages may lead composite restorations to wear and surface degradation, resulting in external pigmentation. Due to its low $\mathrm{pH}$, ethanol can produce erosion and alter some properties of the composites [8]. Ethanol can cause softening of the organic matrix and favor the removal of charge particles during mastication, allowing the formation of a rough surface [1].

The composite resin restorations may present significant darkening and spotting visible to the human eye after immersion in alcoholic beverage, and polishing is not able to minimize or reverse them [9].
Currently most of the popularity of red wines and their use by different socio economic classes and that therefore has access to different brands of composite resins with distinct chemical compositions (varying concentrations of organic and inorganic matrices) raises the question about the possible color change caused by this beverage and whether this stain varies for different composite resins.

This study proposes the null hypothesis that the composite resins have the same color stability in face of the beverages tested.

\section{MATERIAL \& METHODS}

For the development of this research, 90 specimens of three brands of composite resins were made, 30 for Filtek Z350 XT resin (3M ESPE), 30 for IPS Empress Direct resin (Ivoclar Vivadent) and 30 for Grandio ${ }^{\circledR}$ So resin ( Voco), all in A2 color. Their specifications can be observed in the table below (Table I) and the experimental groups in Table II.

Table I - Composition of the composite resins used

\begin{tabular}{|c|c|c|c|}
\hline Material & $\begin{array}{l}\text { IPSEmpress } \\
\text { Direct } \\
\text { (Nanohybrid) }\end{array}$ & $\begin{array}{c}\text { Grandio®So } \\
\text { (Nanoparticulate) }\end{array}$ & $\begin{array}{c}\text { Filtek Z350 XT } \\
\text { (Nanoparticulate) }\end{array}$ \\
\hline Matrix & $\begin{array}{c}\text { TEGDMA, } \\
\text { Bis-GMA, } \\
\text { UDMA, } \\
\text { Bis-EMA }\end{array}$ & $\begin{array}{c}\text { TEGDMA, } \\
\text { Bis-GMA, } \\
\text { UDMA, } \\
\text { Bis-EMA }\end{array}$ & $\begin{array}{c}\text { TEGDMA, } \\
\text { Bis-GMA, } \\
\text { UDMA, } \\
\text { Bis-EMA }\end{array}$ \\
\hline $\begin{array}{l}\text { Composi- } \\
\text { tion } \\
\text { (particles) }\end{array}$ & $\begin{array}{l}\text { Vitro of barium, } \\
\text { ytterbium } \\
\text { trifluoride, } \\
\text { mixed oxides, } \\
\text { silicon dioxide }\end{array}$ & $\begin{array}{l}\text { BHT and } \\
\text { vitoceramic }\end{array}$ & $\begin{array}{l}\text { Zirconia/Silica } \\
(5 \mathrm{a} 20 \mathrm{~nm})\end{array}$ \\
\hline $\begin{array}{l}\text { Particle } \\
\text { Weight } \\
(\%)\end{array}$ & $77.5-79 \%$ & $89 \%$ & $78.5 \%$ \\
\hline $\begin{array}{l}\text { Manufac- } \\
\text { turer }\end{array}$ & $\begin{array}{l}\text { Ivoclair Viva- } \\
\text { dent AG, } \\
\text { Schaan/Liech- } \\
\text { tenstein, } \\
\text { Alemanha }\end{array}$ & $\begin{array}{l}\text { VOCO GmbH, } \\
\text { Cuxhaven, } \\
\text { Alemanha }\end{array}$ & $\begin{array}{l}\text { 3M/ESPE, St Paul } \\
\text { MN, EUA }\end{array}$ \\
\hline
\end{tabular}


Table II - Experimental groups

\begin{tabular}{cccc|} 
& $\begin{array}{c}\text { Empress Direct } \\
\text { (A) }\end{array}$ & $\begin{array}{c}\text { Grandioso } \\
\text { (B) }\end{array}$ & $\begin{array}{c}\text { Z350 } \\
\text { (C) }\end{array}$ \\
\hline $\begin{array}{c}\text { Distilled water (1) } \\
\text { (control group) }\end{array}$ & A1 & B1 & C1 \\
\hline Red wine (2) & A2 & B2 & C2 \\
\hline Vodka (3) & A3 & B3 & C3 \\
\hline
\end{tabular}

The composite resin specimens were prepared through a preformed silicone matrix, 8 $\mathrm{mm}$ in diameter and $2 \mathrm{~mm}$ thick, propped on a glass plate [2]. The composite resin was inserted in a single increment using a titanium spatula for resin (number 6 Indusbello), placed between two glass plates and two strips of polyester, lightly pressed in order to reduce the excesses and minimize the inhibition of reaction by oxygen. Each side was photopolymerized for $20 \mathrm{~s}$ [10]. A photopolymerizer of LED (Radii - SDI) with a density of approximately $1200 \mathrm{~mW} \mathrm{/} \mathrm{cm}^{2}$ was used for the photopolymerization of the resin.

Following that the samples were removed from the matrix and the surface polished with TDV sandpaper discs (TDV Dental Ltda, Pomerode, Santa Catarina, Brazil) using medium (15 at 10,000 $\mathrm{rpm})$, fine (15 at 30,000 rpm) and extrafine (15 s at $30,000 \mathrm{rpm}$ ) grains, with an exchange of discs for every five specimens [11]. After using the superfine disc polishing was done using an Astrobrush ${ }^{\circledR}$ (Ivoclar Vivadent, Shaan, Liechtenstein) silicon carbide tip for $10 \mathrm{~s}$ at $30,000 \mathrm{rpm}$. To complete the finishing and polishing procedure a felt disc (10 $\mathrm{s}$ at 30,000 rpm) was used with Enamelize ${ }^{\circledR}$ diamond paste (Cosmedent, Friedberg, Germany).

Upon finishing and polishing, the specimens were immersed in distilled water for $24 \mathrm{~h}$ at room temperature [12]. All samples were dried with absorbent paper and subjected to an initial color evaluation using the spectrophotometer test (RT - Lovibond series) and their values annotated (initial values).

The CIE (Commission Internationale d'Eclairage) $\mathrm{L} * \mathrm{a} * \mathrm{~b} *$ system was used for color evaluation. The coordinates of $\mathrm{L} *$ are on the black (0) -white axis (100); of a * are in the red $(+a)$ - green $(-a)$ axis; and $b *$, yellow $(+b)$ - blue (-b) [11]. The values of L0, a0 and b0 were determined with the average sample of each composite. At the end of seven days of immersion, a new evaluation was performed and the values of L1, a1 and b1 were stipulated. The calculation of the color difference was performed by $\Delta \mathrm{E}$, from the formula below, where $\Delta \mathrm{L}$ (L1-L0), $\Delta \mathrm{a}(\mathrm{a} 1-\mathrm{a} 0)$ e $\Delta \mathrm{b}$ (b1-b0) [7]:

$$
\Delta \mathrm{E}=\frac{\left[(\Delta \mathrm{L})^{2}+(\Delta \mathrm{a})^{2}+(\Delta \mathrm{b})^{2}\right]}{2}
$$

They were then identified according to their distribution in their groups according to their resin and subgroups according to their solution, and kept immersed for seven days at $37{ }^{\circ} \mathrm{C}$ in a greenhouse in dark environment. The specimens were immersed in sealed plastic containers to prevent evaporation of the solutions [13]. The solutions used were:

- Distilled water (used for the control group);

- Red wine Miolo Selección (Cabernet Sauvignon / Merlot - Campanha, Brazil, 2014) with $12.5 \%$ of alcohol volume;

- Vodca Orloff (1L) with 38\% of alcohol volume.

After seven days of immersion, the specimens were washed in running water for $10 \mathrm{sec}$, dehydrated on absorbent paper and individually submitted to the spectrophotometer for evaluation of final values.

For result analysis were used ANOVA and Tukey's test with Minitab ${ }^{\circledR} 17.0$ software at a significance level of $95 \%$.

\section{RESULTS}

The data obtained was submitted to the normality test and the assumption was met.

In order to analyze the difference between resins and immersion means, the parametric ANOVA and Tukey tests were used at 95\% significance.

Color evaluations were performed after $24 \mathrm{~h}$ of immersion in distilled water at room temperature. After seven days of immersion in the test substances at $37^{\circ} \mathrm{C}$ the $\Delta \mathrm{E}$ was calculated for the statistical analyzes.

In the tables below (Table III and Table IV) one can observe the results found with the ANOVA test. 
Table III - Description of $\Delta \mathrm{E}$ parameters

\begin{tabular}{|lcccc|}
\multicolumn{1}{c}{ Group } & Count & Sum & Mean $\Delta \mathrm{E}$ & Variance \\
$\begin{array}{l}\text { IMMERSION SOLUTION: } \\
\text { IISTILLED WATER }\end{array}$ & & & & \\
Z350 & 10 & 26.7809 & 2.6781 & 0.1736 \\
$\begin{array}{l}\text { GrandioSo } \\
\text { Empress Direct }\end{array}$ & 10 & 43.3523 & 4.3352 & 2.4560 \\
IMMERSION SOLUTION: & 10 & 54.7440 & 5.4744 & 7.0097 \\
RED WINE & & & & \\
$\quad$ Z350 & 10 & 168.8346 & 16.8835 & 2.1850 \\
$\quad$ GrandioSo & 10 & 83.6831 & 8.3683 & 0.8186 \\
$\quad$ Empress Direct & 10 & 212.1389 & 21.2139 & 9.3046 \\
IMMERSION SOLUTION: & & & & \\
VODKA & & & & \\
$\quad$ Z350 & 10 & 48.3473 & 4.8347 & 3.1271 \\
$\quad$ GrandioSo & 10 & 64.2591 & 6.4259 & 57.8924 \\
Empress Direct & 10 & 55.4983 & 5.5498 & 1.5184 \\
& & & & \\
\hline
\end{tabular}

Table IV - Parameters of $\Delta \mathrm{E}$ at $95 \%$ significance level

\begin{tabular}{|c|c|c|c|c|c|c|}
\hline Variation Source & SQ & gl & MQ & $\mathbf{F}$ & $\begin{array}{c}\text { value- } \\
\mathbf{P}\end{array}$ & $\begin{array}{c}\mathbf{F} \\
\text { critical }\end{array}$ \\
\hline \multicolumn{7}{|c|}{$\begin{array}{l}\text { IMMERSION SOLUTION: } \\
\text { DISTILLED WATER }\end{array}$} \\
\hline $\begin{array}{l}\text { Between groups } \\
\text { Inside the groups }\end{array}$ & $\begin{array}{l}39.54398 \\
86.75456\end{array}$ & $\begin{array}{c}2 \\
27\end{array}$ & $\begin{array}{c}19.77 \\
3.21\end{array}$ & 6.153 & 0.006 & 3.354 \\
\hline \multicolumn{7}{|c|}{$\begin{array}{l}\text { IMMERSION SOLUTION: } \\
\text { RED WINE }\end{array}$} \\
\hline $\begin{array}{l}\text { Between groups } \\
\text { Inside the groups }\end{array}$ & $\begin{array}{l}854.2319 \\
110.7744\end{array}$ & $\begin{array}{c}2 \\
27\end{array}$ & $\begin{array}{c}427.12 \\
4.10\end{array}$ & 104.105 & 0.000 & 3.354 \\
\hline \multicolumn{7}{|c|}{$\begin{array}{l}\text { IMMERSION SOLUTION: } \\
\text { VODKA }\end{array}$} \\
\hline $\begin{array}{l}\text { Between groups } \\
\text { Inside the groups }\end{array}$ & $\begin{array}{l}12.70233 \\
562.8407\end{array}$ & $\begin{array}{c}2 \\
27\end{array}$ & $\begin{array}{c}6.35 \\
20.85\end{array}$ & 0.305 & 0.740 & 3.354 \\
\hline
\end{tabular}

In distilled water, there was a statistically significant difference between the groups ( $p<$ 0.01), and Filtek Z350 XT resin had the best color stability among the three resins tested.

In the soaking medium red wine, the resin Grandio $®$ So had the lowest variation, and there was a statistically significant difference $(\mathrm{p}<$ 0.01 ) between groups.

In vodka, the difference between groups was not statistically significant ( $p>0.05)$, and again the Filtek Z350 XT resin presented a smaller variation among the three.

The Tukey test showed that the IPS Empress Direct resin showed a greater staining in red wine and in a statistically significant way.
In vodka, there was no statistically significant change in relation to the control group.

As for the Grandio ${ }^{\circledR}$ So resin, the highest staining occurred in red wine, followed by vodka, both in relation to the control group, and without statistical significance.

For the Filtek Z350 XT resin, the largest stain occurred in red wine, followed by vodka.

Thus, in general, one can observe the behavior of the three resins tested in each beverage in figure 1.

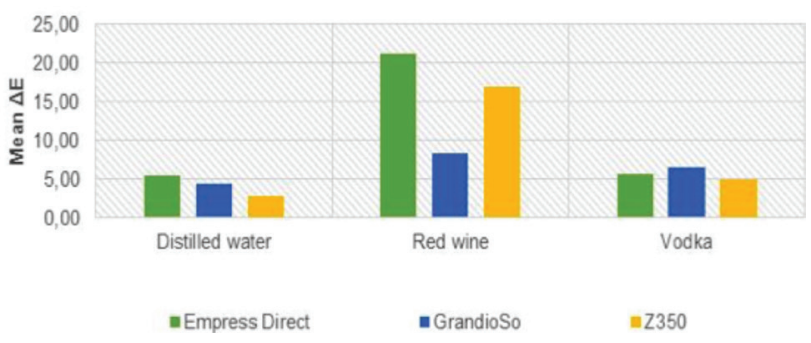

Figure 1- Mean $\Delta \mathrm{E}$ in the immersion media for the three resins tested

\section{DISCUSSION}

Based on the literature reviewed, 90 specimens were prepared, so that each sample group had 10 samples [8-12,14,15]. Each specimen had its width at $8 \mathrm{~mm}$ and its height at $2 \mathrm{~mm}$, as in the study carried out by Kumari et al in 2015 .

For the photopolymerization, a time of 20 $\mathrm{s}$ on each side was determined [10], adding 40 sec per sample, corroborating with the time of $40 \mathrm{sec}$ found in other studies $[3,6,7,16,17]$. In contrast, it is possible to find times of $20 \mathrm{~s}$ of polymerization [5], $30 \mathrm{~s}[9,15]$ or times of $40 \mathrm{~s}$ per side $[13,18,19]$.

Polishing was used as a measure of increasing the surface smoothness of the resin bodies, in order to contribute to the lower exposure to the harmful agents of the alcoholic beverages. The results did not show this protection from staining, just as in 2012, Szesz et al evaluated the possibility of this procedure to minimize or solve the stain caused by beverages, but concluded that there was no effectiveness in the action. In 2013, Falkensammer et al also polished their samples, with no success 
preventing staining. In contrast, in 2007, Yazici et al did not polish their specimens in order not to modify their surfaces, and color changes were again observed, just as in 2013, Al Kheraif et al also did not polish and had significant staining results at the end of the experiments. However, in 2015, Kumari et al evaluated the effect of two types of polishing in preventing color change, and found that the Sof-Lex system is capable of producing a more stain resistant surface when compared to the polishing paste.

The immersion time was determined according to the period where the greatest color change occurs (7 days), as well as in the studies by Bolanho in 2007 and Fontes et al in 2009. Other studies used the mark of one week in their evaluations, but with a temporal continuity, as 14 days $[5,14], 28$ days $[17,18], 60$ days $[9,16]$ and up to 90 days [7].

Grandio ${ }^{\circledR}$ So had the smallest variation (not significantly staining in the presence of vodka, and staining much less than the other resins in the presence of red wine) a fact possibly related to its high inorganic rate. In a similar study, the Grandio type resin had a corroborative action, suffering the least color change [5].

In a study carried out with vodka, in which surface smoothness was evaluated for its alteration after immersion in drinks with low $\mathrm{pH}$, the results were not significant [15]. On the other hand, in another study where the evaluation was of the surface roughness alteration, the results showed that it caused the biggest change only after sparkling wine [1]. In the present study in the tests with vodka, the results were satisfactory since the variations were low and without significance in relation to the distilled water (control). To this fact, it is possible to relate the absence of natural and artificial dyes in the beverage, impacting the resin only the alcoholic composition and the $\mathrm{pH}$. The resin that showed the biggest change was Grandio ${ }^{\circledR}$ So, followed by IPS Empress Direct and Filtek Z350 XT.

Regarding the results of red wine, this one presented the results with the biggest changes and staining. In a study conducted by Freitas et al in 2005, where red wine was compared to coffee, it was found that red wine stained more than coffee. In 2012, Szesz et al tested the possibility of polishing out the staining of some beverages (among them red wine and coffee), where again both stained the samples. The current result also agrees with the study by Falkensammer et al in 2013, where color stability was assessed when immersed in certain beverages, and red wine showed the worst behavior and the most severe discoloration. In addition, this study indicated that the presence of tannin in red wine was more significant to the composite resins change of color than the alcoholic concentration.

The resin that most had its surface stained was IPS Empress Direct, followed by Filtek Z350 $\mathrm{XT}$, which was followed by Grandio ${ }^{\circledR}$ So. In a previous study with red wine, it proved to be a great composite resin staining agent, generating the most severe alterations $[3,5,9,18]$. The composite resin Grandio $®$ So presented a smaller color alteration probably due to its higher particle load concentration (89\%) when compared to the other composite resins analyzed which have 77.5 to $79 \%$ of inorganic load. As the color change is more significant in the organic matrix, the Grandio ${ }^{\circledR}$ So for having less organic part would probably present even greater color stability.

The null hypothesis was therefore rejected once red wine caused more staining, being statistically significant, in the same way the composite resins did not present the same color stability.

\section{CONCLUSION}

According to the results presented, it was possible to conclude that:

- in seven days it is already possible to verify staining of the composite resins in a significant way;

- red wine was the alcoholic beverage that generated the most staining in all tested resins;

- Vodka did not alter color stability significantly;

- the alcoholic concentrations tested had no direct influence on color change;

- the composite resin that presented greater color stability against red wine was Grandio ${ }^{\circledR}$ So, followed by Filtek Z350 XT and finally IPS Empress Direct. 


\section{REFERENCES}

1. Bolanho A. Estudo da degradação de resinas compostas pela ação de bebidas alcoólicas: análise da fluorencência e rugosidade superficial. São José dos Campos. Tese [Doutorado em Odontologia Restauradora] - Faculdade de Odontologia da UNESP;2007.

2. Kumari RV, Nagaraj $H$, Siddaraju K, Poluri RK. Evaluation of the effect of surface polishing, oral beverages and food colorants on color stability and surface roughness of nanocomposite resins. J Int Oral Health. 2015 jul;:7(7):63-70.

3. Freitas ACP, Vieira GF, Garone GM, Garone Netto N. Alteração da translucidez de uma resina composta segundo o meio de imersão. Rev Inst. Ciênc Saúde. 2005 jan-mar;23(1):61-5.

4. Fontes ST, Fernández MR, Moura CM, Meireles SS. Color stability of a nanofill composite: effect of different immersion media. J Appl Oral Sci. 2009 setout; $17(5): 388-91$.

5. Anfe TE,Agra CM, Vieira GF. Evaluation of the possibility of removing staining by repolishing composite resins submitted to artificial aging. J Esthet Restor Dent 2011ago;23(4):260-7.

6. Yazici AR, Celik C, Dayangaç B, Ozgünaltay G. The effect of curing units and staining solutions on the color stability of resin composites. Oper Dent. 2007 nov-dez;32(6):616-22.

7. Al Kheraif AA, Qasim SS, Ramakrishnaiah R, Ihtesham ur Rehman. Effect of different beverages on the color stability and degree of conversion of nano and micrihybrid composites. Dent Mater J.2013;32(2):326-31.

8. Bansal K, Acharya SR, Saraswathi V. Effect of alcoholic and non-alcoholic beverages on color stability and surface roughness of resin composites: an in vitro study.J Conserv Dent. 2012 jul-sep;15(3):283-8.

9. Szesz AL, Martins GC, Pupo YM, Gomes JC, Gomes OMM. Influência do polimento após manchamento de uma resina composta submetidaa diferentes bebidas. Rev Assoc Paul Cir Dent. 2012;66(1):48-52.
10. Sirin Karaarslan E, Bulbul M, YildizE, Secilmis A, SariF,Usumez A. Effects of different polishing methods on color stability of resin composites after accelerated aging. Dent Mater J. 2013;32(1):58-67.

11. Samra AP,Ribeiro DG, Borges CP,Kossatz S. Influence of professional prophylaxis on reducing discoloration of different aesthetic restorative materials. JDent. 2012 dez;40(2):71-6.

12. Jain V,Platt JA, Moore K, Spohr AM, Borges GA. Color stability, gloss, and surface roughness of indirect composite resins. J Oral Sci. 2013 mar;55(1):9-15.

13. Poggio C, Dagna A, Chiesa M, Colombo M, Scribante A. Surface roughness of flowable resin composites eroded by acidic and alcoholic drinks. JConserv Dent. 2012apr-jun;15(2):137-40.

14. Cengiz S, Yüzbaio luE, Cengiz MI, Velio lu N, Sevimli G. Color stability and surface roughness of a laboratory-processed composite resin as a function of mouthrinse.J Esthet Restor Dent. 2015 jul;27(5):314-21.

15. Souza NC, Pozzobon RT, Susin AH, Jaeger F. Avaliação da rugosidade superficial de uma resina composta: influência de diferentes bebidas alcoólicas e uma bebida energética. RG0.2005 jan-mar;53(1):71-84.

16. Badra WV,Faraoni JJ,Ramos RP,Palma-Dibb RG. Influence of different beverages on the microhardness and surface roughness of resin composites. Oper Dent. 2005 mar-apr;30(2):213-9.

17. Tanthanuch S, Kukiattrakoon B, Siriporananon C, OrnprasertN, Mettasitthikorn W, Likhitpreeda S, etal. The effect of different beverages on surface hardness of nanohybrid resin composite and giomer. J Conserv Dent. 2014 mayjun; $17(3): 261-5$

18. Falkensammer F, Arnetzl GV, Wildburger A, Freudenthaler J. Color stability of different composite resin materials. J Prosthet Dent. 2013 jun;109(6):378-83.

19. Han L, Okamoto A, Fikishima M, Okiji T. Evaluation of flowable resin composite surfaces eroded by acidic and alcoholic drinks. Dent Mater J. 2008 jan;27(3):455-65.

\section{Antônio Márcio Resendo do Carmo}

\section{(Corresponding address)}

Rua São Mateus, nº711 apto 401, Bloco B - Bairro: São Ma-

teus, Juiz de Fora/MG - CEP: 36025-001.

Date submitted: 2017 Nov 22

E-mail: antoniomarcio.resende@ufjf.edu.br 